SCIREA Journal of Clinical Medicine

ISSN: 2706-8870

http://www.scirea.org/journal/CM

May 24, 2021

SCIREA

Volume 6, Issue 3, June 2021

\title{
ALLERGIC HYPERSENSITIVITY TO EDIBLE VEGETABLE BULBS DURING ONE YEAR OF FOLLOW-UP
}

Angel San Miguel Rodríguez ${ }^{1,}$ Alicia Armentia Medina ${ }^{2}$, Blanca Martín-Armentia², Sara Martín-Armentia $^{3}$, Angel San Miguel Hernández ${ }^{4}$, Blanca Martín Armentia ${ }^{1}$, Carmen Lozano Estevan ${ }^{5}$, Irene Iglesias Peinado ${ }^{6}$

${ }^{1}$ Research Service. Hospital Universitario Río Hortega. Valladolid. Spain.

${ }^{2}$ Allergy Unit, Hospital Universitario Río Hortega. Valladolid. Spain

${ }^{3}$ Primare care. Paedriatics. Delicias. Valladolid. Spain.

${ }^{4}$ Clinical Analysis Service. Hospital Universitario Río Hortega. Universidad Internacional de la Rioja (UNIR). Spain

${ }^{5}$ Pharmacy Faculty. Complutense University. Madrid. Spain.

${ }^{6}$ Parmacy Faculty. Alfonso X el Sabio University. Madrid. Spain.

Address for correspondence:

Angel San Miguel Hernández ${ }^{4}$

Hospital Rio Hortega.

Dulzaina, 2

47012 Valladolid. SPAIN

E-Mail:_asanmi@saludcastillayleon.es 


\section{ABSTRACT}

Background. Spain occupies the first positions in the world in consumption of edible bulbs (garlic and onion), however there are hardly any references about its ability to cause allergic symptoms.Our objective was to study the allergic sensitization and clinical symptoms associated with garlic and onion in a large sample of allergic patients.

Material and methods. An observational cross-sectional study was conducted, testing an extract of garlic and onion in all patients treated during 2018 in our Allergy service, in total 8,109 patients. 44 aeroallergens and foods were tested, including garlic and onion, with prick and determination of specific IgE. Oral provocations and contact tests were performed if a delayed reaction was suspected. A western blot was performed with the serum of the positive patients to one of these bulbs.

Results. A total of 356,798 skin tests and 4254 specific IgE determinations were performed. Of these 8,109 patients tested, 2508 had various symptoms associated with food intake, and 27 of them had symptoms with bulbs, indicating a prevalence of $3.47 \%$.

The immunodetection allowed to associate the symptoms with a specific LTPs to these bulbs without cross-reactivity with other LTPs of the Mediterranean diet (peach, wheat).

Conclusions. Garlic and onion can cause allergic hypersensitivity in $3.47 \%$ of patients who consume or handle them.

Keywords: Allergic Hypersensitivity, edible bulbs, Garlic, Onion

\section{INTRODUCTION}

Allergic diseases are a true non-infectious epidemic of the 21 st century in developed countries, and can have a fatal outcome. Since any food can behave like an allergen, although some do so more frequently than others $(1,2)$.

Any symptoms that have affected humans have been attributed, at one time or another, to food $(1,3,4)$. The list of foods incriminated in various syndromes is extensive. However, most of the proven food reactions caused only gastrointestinal, skin, and respiratory symptoms.

The study of food hypersensitivity has been full of confusion, unnecessary dietary restrictions, and diagnostic errors. The last classification of hypersensitivity to food endorsed by the WAO 
in 2003 is that of the Nomenclature commission of the European Academy of Allergy and Clinical Immunology.

Spain ranks first in the world in consumption of edible bulbs (garlic and onion), and yet there are hardly any references on its ability to cause allergic symptoms (4-6).

Garlic is a bulbous vegetable that belongs to the family of the Liliáceas (Aliácea), being its scientific name Allium sativum (Allium is a genus of about 500 species belonging to the Liliaceae family). What takes advantage of this plant is the bulb, being widely used as a condiment in the kitchen, mainly in the Mediterranean. Medicinal properties have also been attributed to it, and in fact garlic is used in medicine for the treatment of hypercholesterolemia and prevention of arteriosclerosis (7). It contains vitamins of group B and C, and minerals such as potassium or calcium, in addition to sulfur substances, mainly alliin. The only clinically relevant garlic allergen that has been identified is alliin lyase, which was identified and characterized in 2004, although other possible garlic allergens have been suggested (8). In this same year, cross reactivity was also demonstrated within the Liliaceae family. And cross reactivity has also been seen between this family and grass pollens.

The onion belongs to the lily family, its scientific name being Allium cepa. From it we take advantage of the bulb, as in garlic, which is why these plants are called edible bulbs. It is mainly composed of water, but also contains allicin, alliin (both present in greater amounts in garlic), quercetin, thiopropionic acid (which favors eye irritation), glycolic acid, flavonoids, carbohydrates, amino acids, minerals such as potassium or copper, vitamins. Diallyl disulfide is a major allergen in garlic and onion known to cause contact dermatitis (9)

The Liliaceae family has generally been implicated as a cause of occupational rhinoconjunctivitis and bronchial asthma (10), but little has been said about food allergy in this family, perhaps due, as mentioned in some articles, to its weak allergenicity.

Garlic is well known for causing contact dermatitis, and a known etiologic agent for asthma. But it is a very rare cause of a food allergy. Garlic has been seen to be the most common cause of contact dermatitis on fingers or pulpitis in housewives and caterers. (7) This condition can have various skin manifestations, the most common being chronic pulpitis of the first 3 fingers of hand. 


\section{OBJECTIVES}

Study the allergic sensitization and the clinic associated with garlic and onion in an important sample of allergic patients. So we will really see if it is efficient to include these edible bulbs in routine allergology tests. A total of 8,109 patients attended in an Allergy consultation for 1 year were studied.

\section{MATERIAL AND METHODS}

- Study design: Cross-sectional observational study of the population sent to the Allergy clinic during 2018 to assess sensitization to bulbs.

The protocol was evaluated by the HURH Clinical Research Ethics Committee and informed consent was made in all the diagnostic techniques used.

-Skin tests: To carry out the prick tests, we proceeded according to the standards of the European Academy of Allergy and Clinical Immunology (EAACI), considering positive that test that produced a wheal whose diameter is greater than or equal to $3 \mathrm{~mm}$. Each allergen was tested in duplicate and the results were recorded on a data collection sheet for further digitization.

Skin tests detect sensitization. They were carried out according to EAACI standards. Allergenic extracts: battery of 42 aeroallergens and foods, to which garlic and onion have been added, both in commercial extract and in prick-prick with garlic and Castile onion at 1/100 dilution. In total, 356,798 skin tests were performed.

-Allergenic extracts: Standard battery of aeroallergens and food that included pollens (grasses. Trees, weeds and flowers), mites (Dermatophagoides and storage), fungi (Alternaria, Cladosporium, Aspergillus, Penicillium and Candida), animal antigens and common foods: wheat, barley, rye, egg, milk, legumes, nuts, fish, seafood, Anisakis, profilines (ALK -Abelló, Madrid, and Leti, Barcelona Spain), to which garlic and Castile onion (in extract) have been added commercial and in prick-prick at 1/100 dilution that avoided the irritating effect of allylic acid) to all the patients attended during 2018 , who were a total of 8,109 new patients.

- Determination of specific IGE: These tests detect allergic sensitization, with greater specificity than the prick test and the possibility of quantification. A total of $4254 \operatorname{IgE}$ determinations have been made. 
Of the 8,109 patients tested, 2508 had various symptoms associated with food intake, and of these 27 had bulbous symptoms. Specific IgE: Thermofisher, Upssala, Sweden.

- Oral Provocation: Only 2 patients accepted, double-blind, placebo-controlled. In both lip edema and urticaria with $5 \mathrm{mg}$ of raw garlic masked and powdered in pipermint syrup in the first half hour.

It is the gold standard for allergy diagnostic tests. With them we can differentiate sensitization from clinical allergy. It consisted of a double-blind, placebo-controlled provocation.

- Contact tests (European contact battery): They were performed in patients with pulpitis or dermatitis on the hands after handling these bulbs and in eczematous dermatitis.

- Study of allergenic profiles. The garlic and onion proteins were extracted by suspension in a buffer solution (phosphate buffered saline, $\mathrm{pH}$ : 7.4) for two hours at $4{ }^{\circ} \mathrm{C}$. After centrifugation, the supernatant was separated from the insoluble part and then dialyzed against water, and then freeze-dried the samples.

The protein concentration of both extracts was determined according to the Bradford method (12). The proteins of both extracts were analyzed using the SDS-PAGE technique according to the protocol used by Laemmli (13), in 15\% polyacrylamide gels under reducing conditions. Proteins were visualized using Coomassie R-250 blue staining. In an analogous experiment the proteins were electrophoretically transferred to a polyvinylidene difluoride membrane (BioRad). Allergen binding was analyzed by Western blotting using a mixture of the sera of the patients sensitized to the source and the anti-human IgE peroxidase conjugate (Southern Biotech). Detection reagents (Western Lightning Plus-ECL, Perkin Elmer) were added to visualize the recognized proteins.

An allergen immunodetection was performed with a pool of sera from patients allergic to garlic and another pool of sera from patients allergic to onion, to see which molecules are responsible for the clinic. They were analyzed using SDS-PAGE and Western-Blot techniques.

-Statistical analysis. Statistical analysis was performed with the SPSS version 15.0 program. Pearson's Chi-square test was used to analyze the association between the study variables. In the event that the number of cells with expected values less than 5 was greater than $20 \%$, it was calculated using Fisher's exact test or Likelihood ratio test. The Student's t test was performed for independent samples in the comparison of the mean values and when the number of groups to be compared is greater, the ANOVA will be taken. The non-parametric alternatives used, if the use of the above is not convenient, will be the Mann-Whitney U test 
(for two groups) or the Kruskal Wallis $\mathrm{H}$ test (for more than two groups). In the multivariate analysis, a multinomial logistic regression model was fitted.

- Limitations of the study: Our study aimed to describe the usefulness of the diagnostic techniques used to diagnose hypersensitivity to garlic and onion in an elevated group of patients and in the form of a real-life study. The validity and viability of our study could have been compromised by the fact that it would only detect possible causal allergens in patients with atopic undertones, not being applicable to respiratory pathology or other causes. Nor could we determine whether or not the response obtained to garlic would have clinical value in patients who did not accept the provocation or were asymptomatic because subclinical sensitization, that is, without a clear correlate of disease, to different allergens is described in allergic patients. For this, a study of the clinical evolution of the patients would have to be carried out once the possible bulb involved had been detected.

\section{RESULTS}

In total, 356,798 skin tests and 4,254 determinations of allergen-specific IgE were carried out in 8,109 patients treated during 2018. Of these 8,109 tested patients, 2508 had various symptoms associated with food intake (30.92\% of patients treated).

Of the 2508 patients with symptoms associated with food intake, hypersensitivity to some food was observed in 924 patients (11.39\%).

Among the 924 patients with hypersensitivity to any food, in 27 of them the symptoms were caused by edible bulbs, indicating a prevalence of $2.92 \%$ within patients with food hypersensitivity.

In other words, of 2508 patients with symptoms associated with food intake, $1.07 \%$ are sensitized to garlic or onion.

\section{ALLERGENS INVOLVED IN THE ALLERGIC HYPERSENSITIVITY OF THE SUBJECTS IN THE SAMPLE}

We studied the 181 allergens to which the 4,254 specific IgE determinations were positive (Figure 1): 
- Allergen to which more patients are sensitized in our sample: Lolium perenne or ballica plant.

- Food allergen to which the most patients are sensitized in our sample: milk.

- Garlic and onion accounted for 1\% each in relation to total food.

Of all the patients with eating problems, objective hypersensitivity to any food was observed by skin test, positive specific IgE and provocation if necessary in 924 patients $(11.39 \%)$, and of these 27 were caused by bulbs, indicating a prevalence of $3.47 \% .17$ patients were sensitized to garlic and 10 to onion.

$44 \%$ of the patients with positive tests for garlic and / or onion came from primary care and $37 \%$ from the Digestive consultations. $7.4 \%$ came from Pneumology and Dermatology (2 patients) and Pediatrics (1 patient). The predominant symptoms were chronic diarrhea (14.8\%), followed by dyspepsia (flatulence, poor digestion) in $14.8 \%$, asthma, hives and pulpitis $(7.4 \%)$.

Table 1 shows demographic data, symptoms presented by our patients, and evolution after bulb avoidance with positive tests.

Among the sensitized patients, two professional asthmas were detected by inhalation of bulb vapors in cooks and 2 pulpitis in the index fingers and thumb of the left hand, which were diagnosed by contact tests.

An infant who had never tried garlic was possibly sensitized through breast milk, which consumed garlic very frequently.

The most significant association to other foods was with the LTP of peach and wheat.

Table 1.- Demographic data, symptoms presented by the patients and evolution after avoidance of the bulb with positive tests. (MAP: Primary Care. DIG: Digestive. DER: Dermatology. RES:

Respiratory).

\begin{tabular}{|c|c|c|c|c|c|c|c|c|}
\hline $\mathbf{N}^{\mathbf{o}}$ & $\begin{array}{l}\text { Edad } \\
\text { (años) }\end{array}$ & Sexo & Procedencia & Clinica & $\begin{array}{c}\text { Prick/IgE } \\
\text { bulbos }\end{array}$ & Otros & $\begin{array}{c}\text { Provocación } \\
\text { contacto }\end{array}$ & $\begin{array}{l}\text { Mejoria } \\
\text { evitando }\end{array}$ \\
\hline 1 & 39 & $\mathrm{~F}$ & MAP & Dispepsia & ajo & $\begin{array}{c}\text { Anisakis } \\
\text { Trigo } \\
\text { melocotón }\end{array}$ & & $\mathrm{Si}$ \\
\hline 2 & 19 & $\mathrm{M}$ & MAP & Asma & cebolla & Kiwi piñon & & $\mathrm{Si}$ \\
\hline
\end{tabular}




\begin{tabular}{|c|c|c|c|c|c|c|c|c|}
\hline 3 & 39 & $\mathrm{~F}$ & MAP & Dispepsia & Cebolla & & & $\mathrm{Si}$ \\
\hline 4 & 10 & $\mathrm{~F}$ & MAP & $\begin{array}{c}\mathrm{RC} \\
\text { dispepsia }\end{array}$ & Ajo & $\begin{array}{l}\text { Gramíneas } \\
\text { melocoton }\end{array}$ & & $\mathrm{Si}$ \\
\hline 5 & 13 & $\mathrm{M}$ & MAP & Diarrea & Ajo & Gramíneas & & $\mathrm{Si}$ \\
\hline 6 & 32 & M & MAP & Diarrea & Ajo & $\begin{array}{c}\text { Gramíneas } \\
\text { avellana }\end{array}$ & & $\mathrm{Si}$ \\
\hline 7 & 53 & F & MAP & & Ajo & gramineas & & $\mathrm{Si}$ \\
\hline 8 & 1 & $\mathrm{~F}$ & PED & dispepsia & Ajo & & & $\mathrm{Si}$ \\
\hline 9 & 28 & M & DIG & dispepsia & $\begin{array}{l}\text { Ajo y } \\
\text { cebolla }\end{array}$ & $\begin{array}{l}\text { Gramíneas } \\
\text { melocotón }\end{array}$ & $\mathrm{DCCP}+$ & $\mathrm{Si}$ \\
\hline 10 & 29 & $\mathrm{~F}$ & DIG & dispepsia & cebolla & $\begin{array}{l}\text { Gramíneas } \\
\text { Melocotón } \\
\text { trigo }\end{array}$ & & $\mathrm{Si}$ \\
\hline 11 & 34 & $\mathrm{~F}$ & DIG & Diarrea & Ajo & melocoton & & $\mathrm{Si}$ \\
\hline 12 & 52 & $\mathrm{~F}$ & MAP & Asma RC & Cebolla & acaros & & $\mathrm{Si}$ \\
\hline 13 & 62 & $\mathrm{~F}$ & DER & Pulpitis & Ajo & & $+48 \mathrm{~h}$ & $\mathrm{Si}$ \\
\hline 14 & 43 & $\mathrm{~F}$ & DIG & Diarrea & $\begin{array}{l}\text { Ajo y } \\
\text { cebolla }\end{array}$ & gramineas & & $\mathrm{Si}$ \\
\hline 15 & 22 & $\mathrm{~F}$ & DIG & Dispepsia & Cebolla & & Labial + & $\mathrm{Si}$ \\
\hline 16 & 57 & $\mathrm{~F}$ & DIG & Dispepsia & $\begin{array}{l}\text { Ajo y } \\
\text { cebolla }\end{array}$ & gramineas & & $\mathrm{Si}$ \\
\hline 17 & 34 & $\mathrm{~F}$ & MAP & Urticaria & $\begin{array}{l}\text { Ajo y } \\
\text { cebolla }\end{array}$ & gramineas & & $\mathrm{Si}$ \\
\hline 18 & 41 & $\mathrm{~F}$ & MAP & Urticaria & $\begin{array}{l}\text { Ajo y } \\
\text { cebolla }\end{array}$ & melocoton & & $\mathrm{Si}$ \\
\hline 19 & 28 & $\mathrm{~F}$ & MAP & Dermatitis & Ajo & $\begin{array}{l}\text { Anisakis } \\
\text { gramineas }\end{array}$ & & $\mathrm{Si}$ \\
\hline 20 & 32 & $\mathrm{~F}$ & MAP & $\begin{array}{l}\text { Urticaria y } \\
\text { dispepsia }\end{array}$ & Ajo & & & $\mathrm{Si}$ \\
\hline 21 & 53 & M & RESP & Asma & Ajo & Acaros & $\mathrm{DCCP}+$ & $\mathrm{Si}$ \\
\hline
\end{tabular}




\begin{tabular}{|c|c|c|c|c|c|c|c|c|}
\hline 22 & 19 & F & DIG & Urticaria & Cebolla & Melocoton & & $\mathrm{Si}$ \\
\hline 23 & 25 & F & RES & Asma & Ajo & acaros & & $\mathrm{Si}$ \\
\hline 24 & 37 & F & DIG & Diarrea & & gramineas & & $\mathrm{Si}$ \\
\hline 25 & 40 & F & DIG & Urticaria & Cebolla & melocoton & & $\mathrm{Si}$ \\
\hline 26 & 54 & F & DIG & Diarrea & $\begin{array}{c}\text { Ajo y } \\
\text { cebolla }\end{array}$ & gramineas & & $\mathrm{Si}$ \\
\hline 27 & 38 & M & DER & pulpitis & $\begin{array}{c}\text { Ajo y } \\
\text { cebolla }\end{array}$ & & $+48 \mathrm{~h}$ & $\mathrm{Si}$ \\
\hline
\end{tabular}




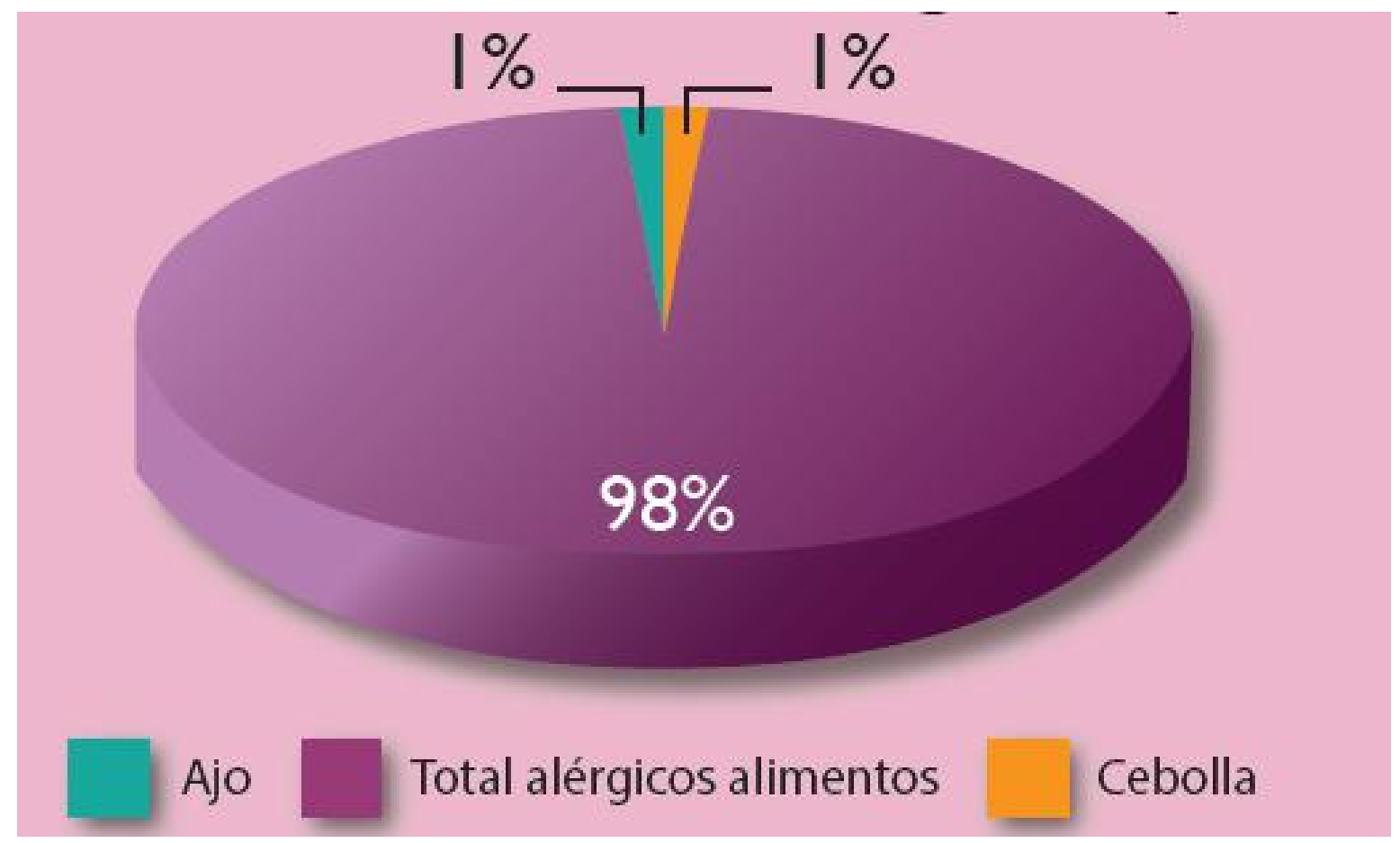

Figure 1.- Allergic to garlic and onion in relation to total food

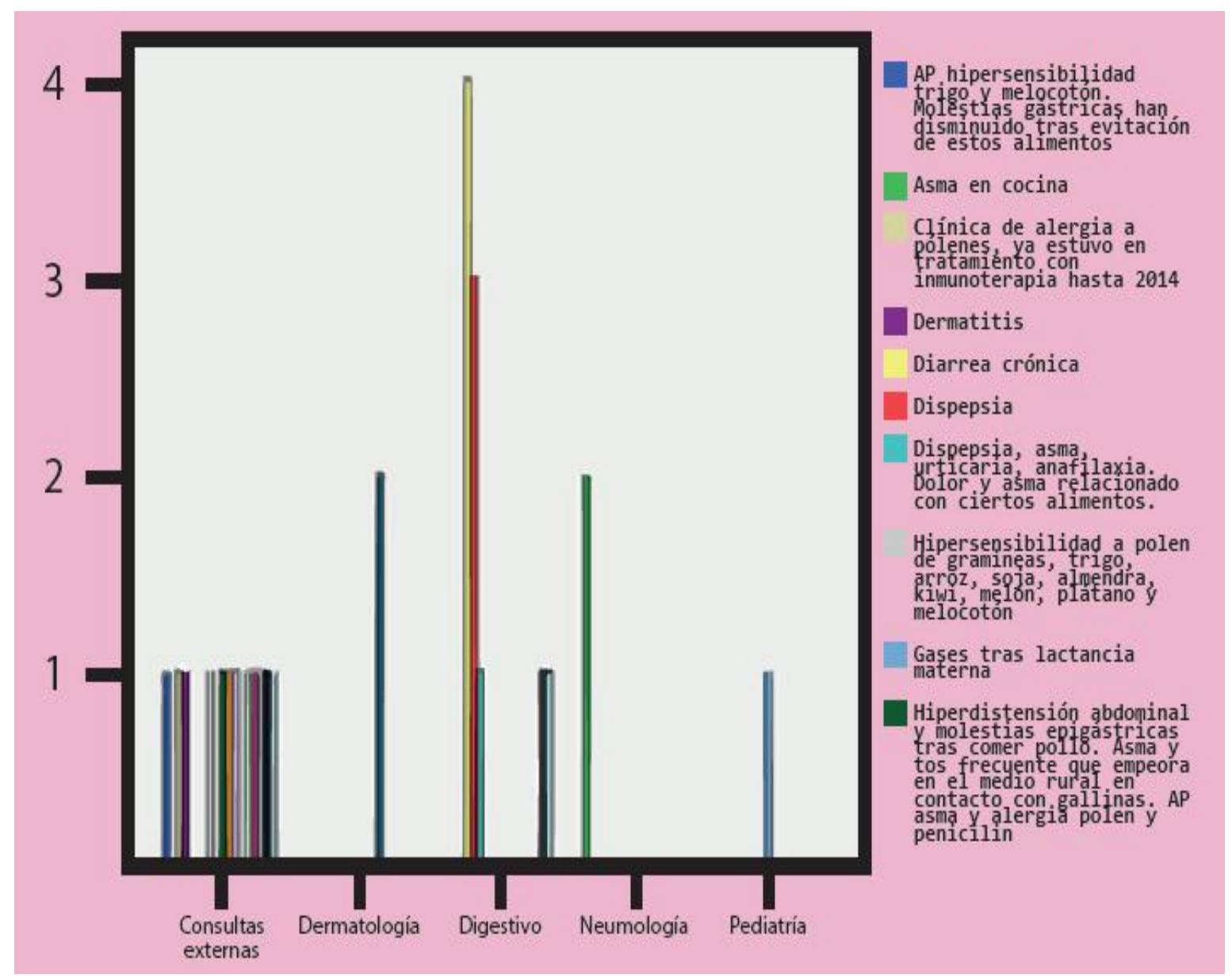

Figure 2. Most frequent clinic of the patients according to the origin. 


\section{WESTERN-BLOT AND SDS PAGE RESULTS}

The reactivity of the sera against the proteins of the garlic and onion extracts is shown in Figure 1. Several components of IgE binding were revealed, in the case of the mixture of sera from patients sensitized to garlic, two proteins were fundamentally recognized of approximately 12 and $60 \mathrm{kDa}$ in both extracts, although the protein of higher molecular weight was revealed with greater intensity in the garlic extract. The serum pool of onionsensitized patients recognized the same proteins in the garlic extract, however a protein of approximately $17 \mathrm{kDa}$ was revealed with high intensity in the onion extract.

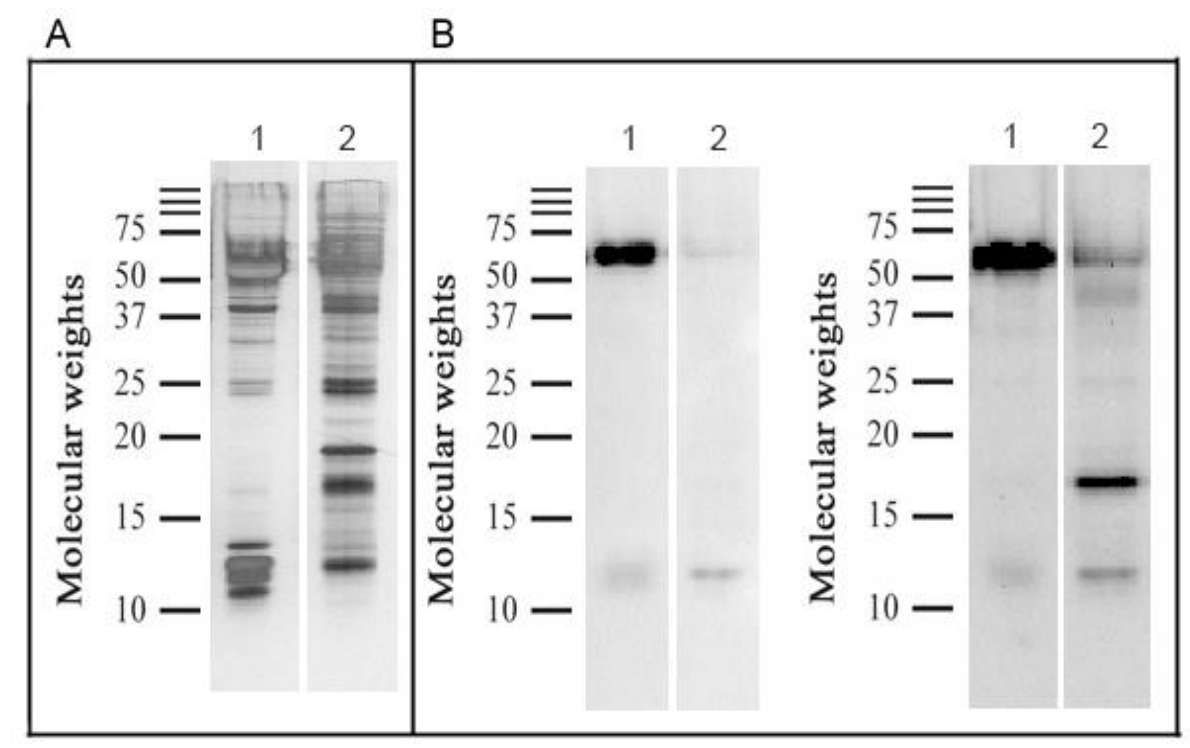

Figure 3. SDS PAGE (A) and IgE-Western blot (B) with serum from patients sensitized to garlic (left) and serum from patients sensitized to onion (right). Calle 1: Garlic, Calle 2: Onion.

\section{DISCUSSION}

The world garlic market, whose cultivation dates back thousands of years, has grown in recent years, and four major world production and consumption centers can be distinguished: Central Asia; the European or Mediterranean, made up of Spain, France and Italy, to which Egypt and Turkey are annexed due to geographical proximity; the North American center, which groups Mexico and the United States; and the South American center, made up of Brazil, Argentina and Chile (4.5).

Globally, China is the leading producer. Regarding the production of the European Union, Spain occupies the first place and, by Autonomous Communities, the one that dedicates the greatest amount of hectares to this cultivation is Castilla-La Mancha, where there are 
numerous localities dedicated to the cultivation of garlic, distributed by the Spanish natural regions of La Alcarria, La Mancha, Mancha Alta, Mancha Baja, Manchuela and Centro, all belonging to the provinces of Albacete, Ciudad Real, Cuenca and Toledo, concentrating most of the production between La Mancha Baja and Centro de Albacete, being a great source of wealth for the Region and a way of life for many families (4-6).

The onion, species Allium cepa, belongs within the plants to the division Magnoliophyta, class Liliopsida, order Asparagales, family Anaryllidaceae, subfamily Allioidae, tribe Alliae, genus Allium. It was one of the first edible plants cultivated, in Central Asia. It was widely used by Greeks and Romans and used between gladiators and legionaries.

Among the edible onions are the green onion (Allium fistulosum), the scallion (Allium ascalonicum) and the leaf or ciboulette (Allium sxhoenoprasum). The irritating substance released by the onion when cut is thiopropanal sulfoxide. The onion bulb is made up of cells attached with peptine.

Onion consumption in Spain is 1,351,495 in thousands of tons, so these bulbs must be considered potential allergens and must be included in food batteries $(7,8)$.

An observational and retrospective study of all patients diagnosed with contact dermatitis with proteins in the last 10 years can be consulted in the Dermatology Skin Allergy Section of the Hospital de Valencia, obtaining that only $3.7 \%$ were caused by meat of pork, garlic and anisakis (10).

As we have already pointed out, garlic is a very rare cause of food allergy, and as such we mainly find isolated cases in the literature. The case of a woman who experienced an anaphylactic reaction after eating garlic has been described. This patient was also sensitized to pollen and nuts. Also in 2018, a case of a 9-month-old infant is described who, after accidental intake of homemade garlic sauce, started with generalized erythema and cough. In our series, a young man presented anaphylaxis after eating raw onion and 2 patients (a cook and a cook) presented professional asthma when cutting garlic. Two patients also had pulpitis related to garlic, so these bulbs would be considered as professional allergens $(16,17,18)$.

Onion is also implicated in cases of contact dermatitis, but there is very little about food allergies, finding mainly isolated cases from patients. The first time that a monosensitization to the heat labile component of onion is described in the literature is in an article published in 2000 , in a 44-year-old patient. The patient presented an anaphylactic reaction after ingesting raw or lightly cooked onion, even with loss of consciousness. But when eating well-cooked 
onions, she did not present any clinic. A case of urticaria and mouth itch after ingestion of raw onion has also been described, with a history of rhinoconjunctivitis and urticaria in contact with mugwort and mouth itch with peach peel, finding that LTP is an important allergen in food allergy to onion. $(13,14,19,20)$. In 2015 , a genetic analysis of the onion bulb was carried out in order to identify possible onion allergens (9).

In 2013, a study was carried out in 108 Saudi patients consisting of evaluating the presence of specific IgE for garlic and onion in patients who were already being studied for food allergies. Of the 108 patients, 15 of them had IgE for garlic and or onion in the serum, 12 of them having antibodies for both garlic and onion. Thus, it could be seen that a considerable number of patients were sensitized to these foods. (12)

\section{CONCLUSIONS}

Our study provides the need to assess garlic and onion sensitization in food allergies with an unclear cause, given their high presence in the Mediterranean diet. In addition, also in people with dyspepsia and chronic diarrhea.

The prevalence found (3.4\%) indicates that there is a higher degree of tolerance than that presented by other foods, but not negligible. In fact, we found a young man with anaphylaxis from eating onion. A response to similar proteins is demonstrated in the two bulbs studied (12 and $60 \mathrm{KDa}$ respectively), and a $17 \mathrm{KDa}$ protein in the onion extract.

Immunodetection allowed symptoms to be associated with specific LTPs to these bulbs without cross-reactivity with other LTPs in the Mediterranean diet (peach, wheat) $(19,20)$.

\section{REFERENCES}

[1] Sampson HA, Mendelson L, Rosen JP. Fatal and nearly fatal anaphylactic reactions to food in children and adolescents. N Engl J Med 1992; 327: 380-384.

[2] Gabinete de prensa de la SEAIC. La leche, el huevo y el pescado son los principales alergenos en la infancia. Webmaster: webmasterseaic@seaic.es. 2002.

[3] Martín Esteban M. Alimentación y alergia. En: Polanco I Eds. Nutrición profiláctica y terapeútica. Saned. Madrid. 1991;95-112 
[4] Fritsch RM, Friesen N. Chapter 1: Evolution, Domestication, and Taxonomy. En: Rabinowitch HD, Currah L. Allium Crop Science: Recent Advances. Wallingford, UK: CABI Publishing. 2002. p.9-10.

[5] Brewster JL. Onions and other vegetable alliums (1st edición). Wallingford, UK: CAB International. 1994. p. 16.

[6] Coultate T. Foof. The chemistrry of its components. RSC Publishing. 2009. p. 302-303.

[7] Cantwell, Marita I. (2002). Appendix: Summary Table of Optimal Handling Conditions for Fresh Produce. En: Kader, A. A. Postharvest Technology of Horticultural Crops $\left(3^{\mathrm{a}}\right.$ edición). Oakland, California: University of California, Agriculture and Natural Resources, Publication 3311. 2002. p. 516.

[8] Allium cepa. Tropicos.org. Missouri Botanical Garden. Disponible en: http://www.tropicos.org/name/18401646.

[9] Nicolini, Giacomo. Enciclopedia Botanica Motta. Volume primo, Milano, Federico Motta Editore, 1960, p. 76.

[10] Allium cepa. En: The Plant List, version 1.1. Disponible en: http://www.theplantlist.org/tpl/record/kew-295261.

[11] Cantisani C, Visconti B, Paolino G, Frascani F, Tofani S, Fazia G, Calvieri S. Unusual food allergy: Alioidea allergic reactions overview. Recent Pat Inflamm Allergy Drug Discov. 2014; 8(3):178-84.

[12] Almogren A, Shakoor Z, Adam MH. Garlic and onion sensitization among Saudi patients screened for food allergy: a hospital based study. Afr Health Sci. 2013;13(3): 689-93.

[13] Jiménez-Timon A, Rodríguez Trabado A, Hernández Arbeiza FJ, Porcel Carreño S, Rodríguez Martín E, Agustín Herrero J, Cobo López R. Anterior rhinomanometry as a diagnostic test in occupational allergy caused by Liliaceae. Allergol Immunopathol (Madr). 2002; 30(5): 295-9.

[14] Bradford MM. A rapid and sensitive method for the quantitation of micro-gram quantities of protein utilizing the principle of protein dye binding. Anal. Biochem.1976; 72:248-254

[15] Laemmli UK. Cleavage of structural proteins during the assembly of the head of bacteriophage T4. Nature. 1970; 227:680-5.

[16] Rothman S, Dondo, G. Cebolla (Allium cepa). Cátedra de Horticultura, Departamento producción vegetal, Facultad de Ciencias Agropecuarias, Universidad Nacional de Entre Ríos. Disponible en: www.fca.uner.edu.ar/files/academica/deptos/catedras/horticultura/cebolla.pdf 
[17] Celestino Mutis J. Jardín Botánico. Cebolla Cabezona. Disponible en: www.rjb.csic.es/jardinbotanico/jardin/index.php?Cab=111\&Pag=214

[18] Anthos. Sistema de información sobre las plantas de España, RJB-CSIC, Madrid.

[19] Blanco Guerra C, Almeida L, Castillo R, Sánchez-Monge R, Fernández Rivas M. Síndromes de reactividad cruzada en la alergia a los alimentos. Capítulo 49. Alergia a alimentos. p 915-938. Disponible en: https://www.seaic.org/wpcontent/plugins/download.../download.php?id...Alimentos...

[20] Pastorello EA, Incorvaia C, Ortolani C. Cross-reactions in food allergy. Clin Rev Allergy Immunol 1997; 15:415-27

[21] Varjonen E, Savolainen J, Mattila L, Kalimo K. IgE binding components of wheat, rye, barley and oats recognized by immunoblotting analysis with sera from adult atopic dermatitis patients. Clin Exp Allergy 1994; 24 :481-9.

[22] Jones SM, Magnolfy Ch F, Cooke S K, Sampson H A. Immunologic cross-reactivity among cereal grains and grasses in children with food hypersensitivity. J Allergy Clin Immunol 1995; 96:341-51.

[23] Saarinen KM, Savilahti E. Infant feeding patterns affect the subsequent immunological features in cow's milk allergy. Clin Exp Allergy 2000; 30:400-6. 